\title{
Importance of the Antibody Response in the Outcome of Virus-Induced Diseases of the Central Nervous System
}

\author{
Antibody Modulation of Coronavirus Encephalitis in \\ a Mouse Model
}

Pierre J. Talbot, Robert L. Knobler, and Michael J. Buchmeier

\section{INTRODUCTION}

The immune response induced after exposure to a viral agent is aimed at preventing or at least limiting the deleterious effects of the infection. Thus, an acute viral illness can be aborted into a subclinical or inapparent infection. For example, only about one-half of adults with circulating antibodies to mumps virus recall having had the disease (Luria et al., 1978). On the other hand, the immune response may alter the course of disease. For example, human viral diseases such as subacute sclerosing panencephalitis (Vandvik, 1973) and progressive rubella panencephalitis (Wolinsky et al., 1976) occur in the presence of high titers of antibodies to measles and rubella viruses, respectively. Alternatively, a viral infection may trigger an autoimmune disease, possibly as a result of molecular mimicry or the sharing of antigenic sites between virus and host cell components (Fujinami and Oldstone, 1985) or rather the destruction of cells with release of cellular antigens not normally available to the immune system (Gonzalez-Scarano and Nathanson, 1985). Finally, the immune response to the infectious agent may contribute to the disease via immune-mediated tissue injury (Buchmeier and Knobler, 1984).

We have made use of an animal model to study the importance of the antibody response to an infectious agent of the central nervous system in modulating the outcome of the infection. The JHM strain of murine hepatitis virus (MHV-JHM) is a neurotropic member of the Coronaviridae (Siddell et al., 1983), a group of enveloped positive-polarity single-stranded RNA viruses. The agent was first isolated in 1949 from brains of mice

Pierre J. Talbot - Virology Research Center, Institut Armand-Frappier, Laval, Quebec H7N 4Z3, Canada. Robert L. Knobler - Department of Neurology, Jefferson Medical College, Philadelphia, Pennsylvania 19107. Michael J. Buchmeier - Department of Immunology, Scripps Clinic and Research Foundation, La Jolla, California 92037. 
with paralytic symptoms (Cheever et al., 1949) and shown to be involved in encephalitis and demyelination (Bailey et al., 1949). Fatal encephalitis is associated with significant loss of neurons, cells to which susceptibility of mice could be mapped (Knobler et al., 1981a). Infrequent survivors or mice infected with attenuated temperature-sensitive mutants of MHV-JHM showed chronic recurrent demyelination as a result of oligodendrocyte infection (Lampert et al., 1973; Weiner, 1973; Haspel et al., 1978; Knobler et al., 1981b, 1982). This experimental model of a neurotropic agent interacting with the central nervous system is especially relevant to studies on the possible viral etiology of mental disorders such as multiple sclerosis (Gonzalez-Scarano and Nathanson, 1985) in view of the observation that a large proportion of the human population shows circulating anticoronavirus antibodies (MacNaughton, 1982). Moreover, multiple sclerosis patients show intrathecal synthesis of antibodies to coronaviruses (Salmi et al., 1982) as well as other viruses such as measles (Norrby, 1978).

Structural proteins of MHV include a nucleocapsid protein $\mathrm{N}$ (56,000 daltons) and two glycoproteins E1 (23-25,000 daltons) and E2 (90-100,000 and 180-200,000 daltons) (Siddell et al., 1982; Sturman and Holmes, 1983). The small glycoprotein E1 contains O-linked oligosaccharides (Holmes et al., 1981; Niemann and Klenk, 1981), is deeply embedded in the viral envelope (Armstrong et al., 1984), and interacts with the internal $\mathrm{N}$ protein in a matrixlike fashion (Sturman et al., 1980). The large glycoprotein E2 is associated with the virion petal-shaped peplomers, contains $\mathrm{N}$-linked oligosaccharides, and appears to be a dimer of two subunits of identical size (Sturman et al., 1985). We have raised a library of monoclonal hybridoma antibodies against the structural proteins of MHV-JHM to use as specific probes of the biology and biochemistry of this virus and its associated CNS disease. In our initial studies, we could identify the E2 glycoprotein as being involved in attachment to susceptible cells and spread of virus by cell-cell fusion (Collins et al., 1982). More recently, we could define three topographically distinct antigenic sites on this protein that were involved in in vitro neutralization (Talbot $e t$ al., 1984). The object of the present report is to describe our findings with regard to the importance of specific antibodies in modulating CNS disease induced by the coronavirus MHV-JHM.

\section{MODULATION BY MONOCLONAL ANTIBODY OF NEUROLOGICAL DISEASE INDUCED IN MICE BY THE WILD-TYPE STRAIN OF MHV-JHM}

Passive transfer by intraperitoneal injection of monoclonal antibodies $(0.2 \mathrm{ml}$ ascites fluids) directed to two of three neutralization sites on the E2 glycoprotein of MHV-JHM protected 4- to 6-week-old BALB/c St mice from a normally lethal intracerebral virus challenge (30-150 LD $\mathrm{LD}_{50}$ ) given 1 or 2 days later (Buchmeier et al., 1984), as shown in Table 1.

Significant protection (50\%) was afforded with an intraperitoneal dose as low as 1 $\mu \mathrm{g}$ per gram of mouse body weight $(25 \mu \mathrm{l}$ of $5 \mathrm{~B} 19.2$ ascites fluid containing $1 \mathrm{mg} / \mathrm{ml}$ specific IgG1). Protected animals showed a drastic reduction in virus titers (20-fold in brain and more than 100-fold in liver), indicating a substantial decrease of virus replication in both the CNS and peripheral compartments. The protection afforded by appropriate monoclonal antibody was both prophylactic and therapeutic, since more than $80 \%$ of 
Table 1. Passive Protection by Monoclonal Antibodies to MHV-JHM

\begin{tabular}{lcccc}
\hline Antibody & Ig subclass & Epitope recognized & $\begin{array}{c}\text { Neutralization } \\
\text { in vitro }\end{array}$ & $\begin{array}{c}\text { Protection } \\
\text { in vivo }\end{array}$ \\
\hline 5B19.2 & IgG1 & $\mathrm{A}(\mathrm{E} 2)$ & + & + \\
$5 \mathrm{~B} 170.3$ & IgG1 & $\mathrm{A}(\mathrm{E} 2)$ & + & + \\
$5 \mathrm{~A} 13.5$ & IgG2A & $\mathrm{B}(\mathrm{E} 2)$ & + & + \\
4B11.6 & IgG2A & $\mathrm{C}(\mathrm{E} 2)$ & + & - \\
$5 \mathrm{~B} 21.5$ & IgG1 & $\mathrm{D}(\mathrm{E} 2)$ & - & - \\
$5 \mathrm{~B} 93.9$ & IgA & $\mathrm{D}(\mathrm{E} 2)$ & - & - \\
$5 \mathrm{~B} 207.7$ & IgG2B & $\mathrm{E}(\mathrm{E} 2)$ & - & - \\
$5 \mathrm{~B} 216.8$ & IgG2A & $\mathrm{E}(\mathrm{E} 2)$ & - & - \\
$5 \mathrm{~B} 119.4$ & IgG2A & $\mathrm{A}(\mathrm{E} 1)$ & - & - \\
$5 \mathrm{~A} 5.2$ & IgG3 & $\mathrm{B}(\mathrm{E} 1)$ & - & - \\
$5 \mathrm{~B} 128.3$ & IgG3 & $\mathrm{C}(\mathrm{E} 1)$ & - & - \\
4B6.2 & IgG1 & $\mathrm{A}(\mathrm{N})$ & - \\
\hline
\end{tabular}

mice could be protected by passive transfer of antibody 5B19.2 1 day after virus inoculation, which argues for a protection mechanism more complex than simple in vivo neutralization (Buchmeier et al., 1984). Histopathological examination and antigen localization studies showed that protection from normally fatal encephalitis was a result of a sparing of neurons but that oligodendrocytes were still infected, which resulted in a chronic subacute demyelinating disease (Buchmeier et al., 1984) similar to that observed after infection with the attenuated mutant $t s 8$ (Haspel et al., 1978). Indeed, passive transfer of monoclonal antibody 5B19.2 could not protect mice from $t s 8$-induced demyelination, which suggests that antibody can protect neuronal cells from MHV-JHM infection but does not similarly protect oligodendrocytes (Buchmeier et al., 1984).

\section{PROTECTION BY MONOCLONAL ANTIBODY OF NUDE MICE FROM wt MHV-JHM ENCEPHALITIS}

In order to pinpoint more precisely the primary antibody dependence of the protection from coronavirus encephalitis, we repeated the passive monoclonal antibody transfer studies in the athymic nude mouse model, where it is generally believed that cellular Tcell-dependent immune responses are at a minimal level (Rygaard, 1975). We found that the survival time of $n u / n u$ BALB/Wehi mice was significantly increased by a single intraperitoneal administration of $0.2 \mathrm{ml}$ ascites fluid of monoclonal antibody 5B19.3 (a cloned hybridoma line identical to 5B19.2) 2 days prior to intracerebral challenge with 50 PFU of $w t$ MHV-JHM, as shown in Fig. 1.

\section{PROTECTION BY MONOCLONAL ANTIBODY OF NUDE MICE FROM tS8 MHV-JHM ENCEPHALITIS}

Unlike conventional $\mathrm{BALB} / \mathrm{c}$ mice, nude mice were only partially protected from coronavirus encephalitis (Buchmeier et al., 1984; Fig. 1), probably because of a much 


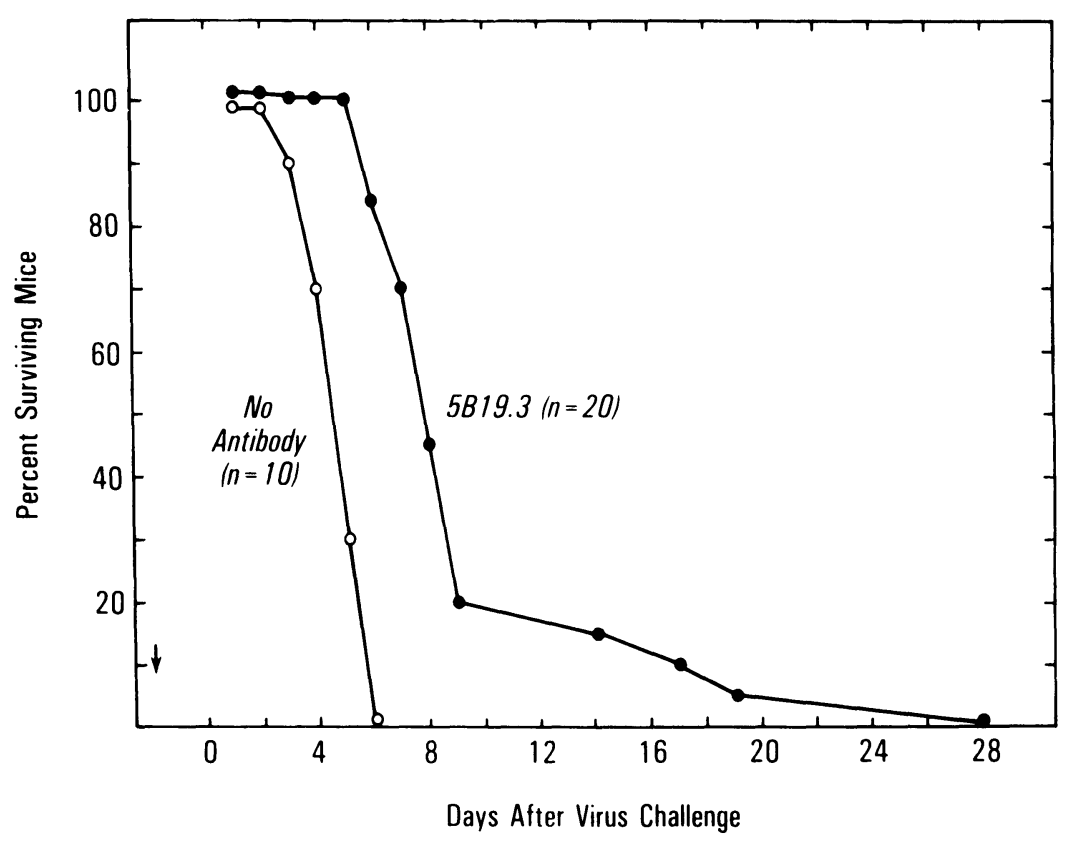

Figure 1. Passive monoclonal antibody protection of nude mice from normally fatal $w t$ JHM virus-induced encephalitis ( $n=$ number of mice per group).

higher virulence of the wild-type JHM virus in nude mice. Thus, we turned to the attenuated $t s 8$ mutant of MHV-JHM (Haspel et al., 1978). An intracerebral $t s 8$ virus challenge that is normally not lethal in conventional BALB/c mice killed all 6- to 8week-old $n u / n u$ BALB/Wehi mice within 7 to 8 days. Therefore, the $t s 8$ infection of nude mice provided an excellent alternative experimental model to study antibody modulation of coronavirus encephalitis in the absence of $\mathrm{T}$-cell responses.

Nude mice given a single intraperitoneal dose $(0.4 \mathrm{ml}$ ascites fluid $)$ of monoclonal antibody 5B19.3, directed against neutralization epitope $A(E 2)$, survived for up to 3 weeks following virus inoculation of as much as $10^{4}$ PFU given 2 days after antibody transfer (Fig. 2A). Unprotected mice were killed with virus doses as low as $0.1 \mathrm{PFU}$, which corresponded to approximately $1 \mathrm{LD}_{50}$ (Fig. $2 \mathrm{~B}$ ).

Nude mice could be spared for longer periods of time by repeated antibody injections (Fig. $3 \mathrm{~B})$. On the other hand, nude mice given a single dose of monoclonal antibody $5 \mathrm{~A} 13.5$, directed against a distinct neutralization epitope $B(E 2)$, survived indefinitely from a $100 L_{50}$ $t s 8$ virus challenge given 2 days later (Fig. 3A). Unprotected mice were all killed within 7-8 days (Fig. 3C) and showed signs of clinical illness a few days before that.

The increased protective potential of antibody 5A13.5 correlated with an approximately fivefold higher in vitro neutralization titer compared to antibody 5B19.2 (Buchmeier et al., 1984). 
Figure 2. Passive monoclonal antibody protection of nude mice from normally fatal $t s 8$ virus-induced encephalitis $(n=$ number of mice per group;

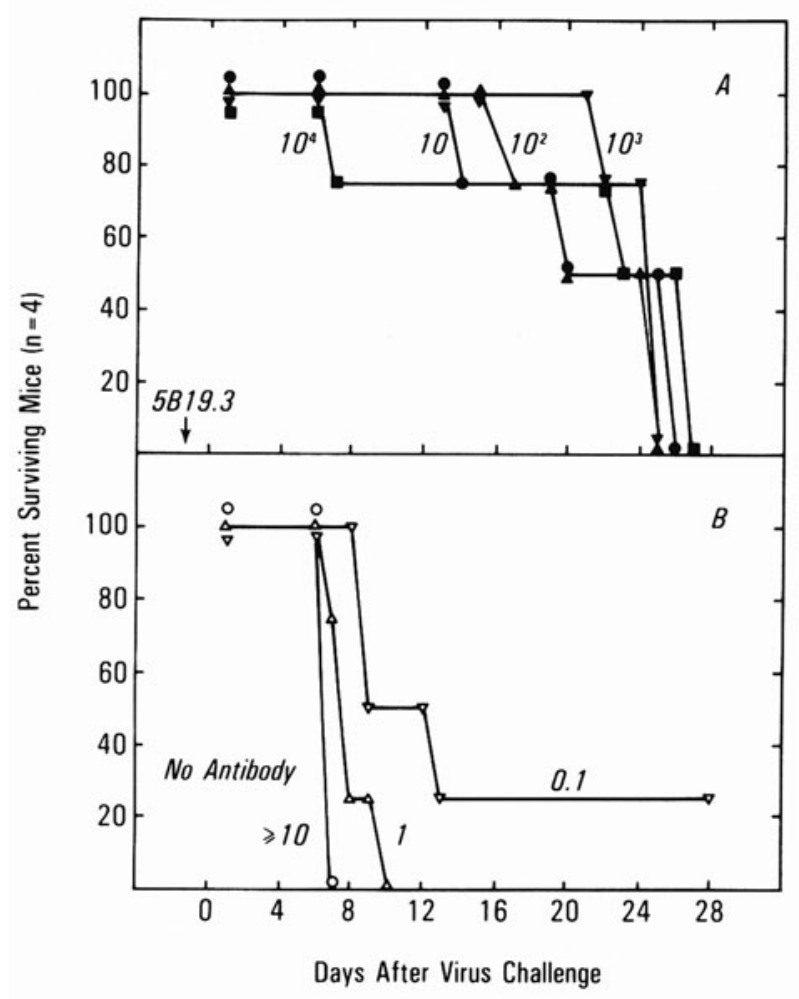

PFU as indicated).

\section{ANTIBODY RESPONSE OF NUDE MICE UPON tS8 MHV-JHM INFECTION}

A possible explanation of the increased susceptibility of nude mice to the attenuated ts 8 mutant of MHV-JHM was a deficient immune response to the infectious agent. Thus, we measured the antibody response of these mice after a nonlethal peripheral virus challenge. Results are shown in Fig. 4. Homozygous nu/nu mice made a much lower antibody response to MHV-JHM than their heterozygous $n u /+$ littermates, which bear the recessive nude gene. Circulating viral antibody titers were eight- to 50-fold lower in nude mice, and separate experiments showed that this low level of antibodies was not sufficient to confer protection against a subsequent intracerebral challenge (data not shown).

\section{PASSIVE TRANSFER OF PROTECTION FROM tS8 MHV-JHM ENCEPHALITIS BY IMMUNE SERUM}

Previous studies have provided insight into the potential role of selected specific antibodies in leading to host survival from fatal infection. However, hybridoma antibodies 


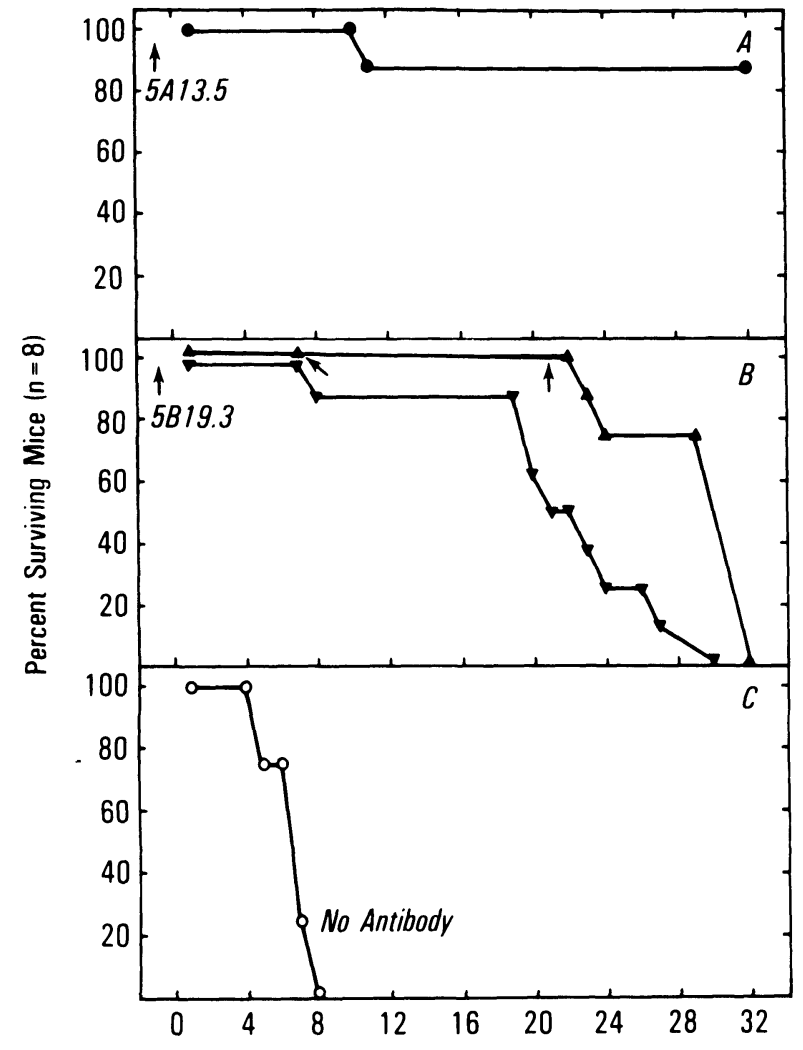

Days After Virus Challenge
Figure 3. Passive monoclonal antibody protection of nude mice from normally fatal $t s 8 \mathrm{JHM}$ virus-induced encephalitis ( $n=$ number of mice per group). Antibody was injected as a single intraperitoneal dose $(0.4 \mathrm{ml}$ ascites fluid) 2 days before intracerebral 100 $\mathrm{LD}_{50}$ virus challenge $(\boldsymbol{O}, 5 \mathrm{~A} 13.5 ; \mathbf{\nabla}$, 5B19.3). Alternatively, antibody 5B19.3 was given in three identical doses 2 days before and 1 and 3 weeks after virus challenge $(\boldsymbol{\Delta})$. Unprotected mice were all killed within 7-8 days $(O)$.

produced in the form of ascites fluids represent concentrations of specific antibodies likely never encountered in the course of an antibody response to viral infection (Talbot et al., 1985). Thus, in order to establish more firmly the relevance of the antibody protection studies in the context of MHV-JHM infection of nude mice, we attempted to transfer protection to these immunodeficient animals with an immune serum produced in normally responding mice. For that purpose, BALB/Wehi mice were hyperimmunized with $w t$ MHV-JHM injections, and their serum was collected 1 week after the last injection. Virus-specific antibody titers were determined by an enzyme-linked immunosorbent assay (Talbot et al., 1984), a modification of which was used to quantify antibodies directed against specific epitopes on the viral proteins (Talbot et al., 1985). Three different immune serum pools were used for passive protection studies, and the results are shown in Table 2. Monoclonal antibody ascites fluids were used for comparison.

A single peripheral administration of one of the three immune serum pools protected nude mice from a normally lethal virus challenge. These animals survived for similar periods ( 3 weeks or more) to animals protected with a single dose of monoclonal antibody 5B19.3. Quantitation of specific antibodies in immune sera showed that protection potential correlated with titers of antibodies to epitope $A(E 2)$, which is the target on the E2 glycoprotein of neutralizing and protecting antibodies (Talbot et al., 1984). Indeed, passive transfer of immune serum containing $0.52 \mu \mathrm{g} / \mathrm{ml}$ antibodies against epitope $A(E 2)$ 
Figure 4. Antibody response of $n u / n u$ and $n u /+$ BALB/Wehi mice upon intraperitoneal inoculation of $10^{4}$ PFU ts8 MHV-JHM. Viral-specific titers were measured by enzyme-linked immunosorbent assay (Talbot et al., 1984) in individual mice in groups of six.

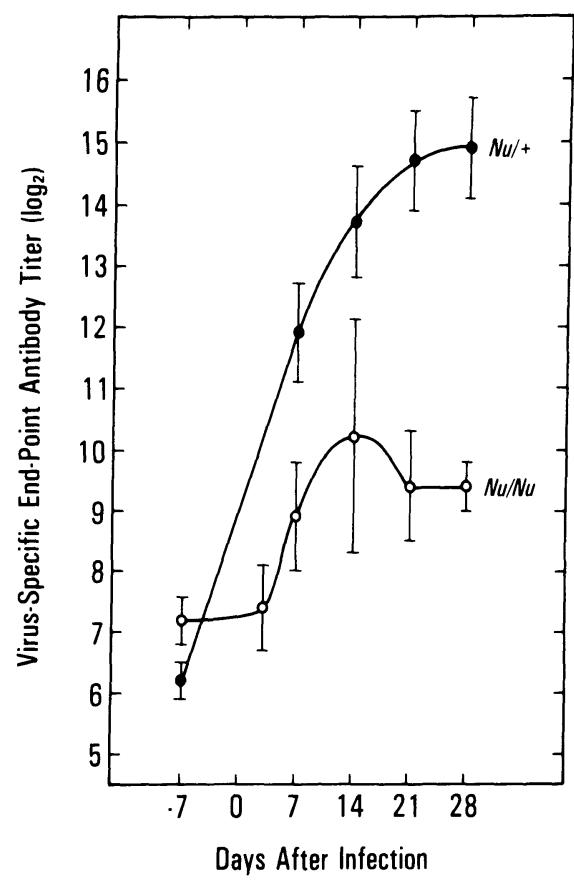

Table 2. Passive Transfer of Protection from ts8 MHV-JHM Encephalitis with Immune Serum and Monoclonal Antibody

\begin{tabular}{|c|c|c|c|c|c|c|}
\hline \multirow{3}{*}{$\begin{array}{l}\text { Antibody } \\
\text { source }\end{array}$} & & \multirow{3}{*}{$\begin{array}{l}\text { Total } \\
\left(\log _{2}\right)^{b}\end{array}$} & \multirow{2}{*}{\multicolumn{3}{|c|}{$\frac{\text { MHV-JHM antibody titer }}{\text { Epitope-specific }(\mu \mathrm{g} / \mathrm{ml})}$}} & \multirow{3}{*}{$\begin{array}{c}\text { Passive } \\
\text { protection }^{c}\end{array}$} \\
\hline & & & & & & \\
\hline & & & $\mathrm{A}(\mathrm{E} 2)$ & $\mathrm{C}(\mathrm{E} 2)$ & $\mathrm{B}(\mathrm{E} 1)$ & \\
\hline \multicolumn{7}{|c|}{$\begin{array}{l}\text { Immune serum } \\
\text { pool }^{a}\end{array}$} \\
\hline 1 & & 17.3 & 0.21 & 3.3 & 3.7 & - \\
\hline 2 & & 18.5 & 0.28 & 3.8 & 7.0 & - \\
\hline 3 & & 19.0 & 0.52 & 4.3 & 6.5 & + \\
\hline \multicolumn{7}{|c|}{$\begin{array}{l}\text { Monoclonal antibody } \\
\text { ascites fluids }\end{array}$} \\
\hline $5 B 19.3$ & $\mathrm{~A}(\mathrm{E} 2)$ & 10.5 & 1000 & 0 & 0 & + \\
\hline 4B11.6 & $\mathrm{C}(\mathrm{E} 2)$ & 11.8 & 0 & 730 & 0 & - \\
\hline $5 A 5.2$ & $\mathrm{~B}(\mathrm{E} 1)$ & 9.5 & 0 & 0 & 630 & - \\
\hline \multicolumn{7}{|c|}{ 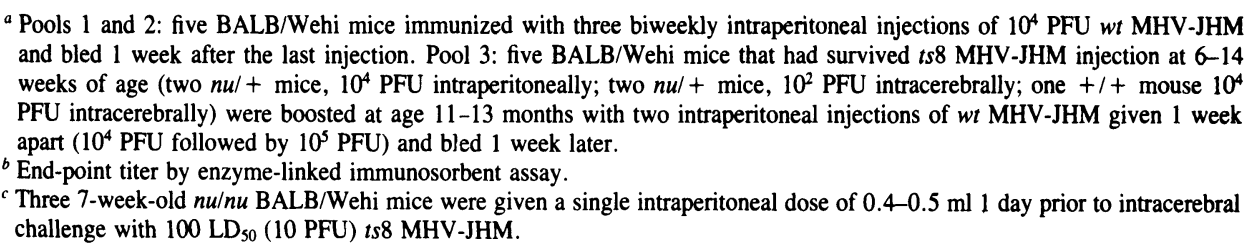 } \\
\hline
\end{tabular}


was sufficient to confer protection, whereas an immune serum containing $0.28 \mu \mathrm{g} / \mathrm{ml}$ of such antibodies failed to protect mice. Separate studies have shown that mice do generate such protecting levels of antibodies upon experimental MHV-JHM infection (Talbot $e t$ $a l ., 1985)$. Thus, the increased susceptibility of nude mice to $t s 8$ MHV-JHM can be overcome by passive transfer of appropriate antibodies.

\section{CONCLUDING REMARKS}

Studies described in the present report emphasize the importance of an appropriate antibody response in modulating the outcome of the coronavirus MHV-JHM-induced central nervous system disease. Antibody response at the level of individual epitopes on a viral glycoprotein may be a critical determinant of the outcome of CNS infection. Thus, the analysis of the antibody response to an infectious agent and its relevance to CNS disease must include a quantitation of specific protecting antibodies. Such quantitation could reveal an unsuspected importance of antibodies in neurological disorders (Sorensen et al., 1984; Woodward et al., 1984).

The murine coronavirus MHV-JHM thus represents an interesting experimental model for the analysis of the importance of antibody response in the CNS disease. Further studies of this model should include a quantitation of intrathecal antibody response. Indeed, previous studies have indicated intrathecal synthesis of MHV-JHM specific antibodies (Fleming et al., 1983; Sorensen et al., 1984), a phenomenon also noted in human CNS diseases such as subacute sclerosing encephalitis and multiple sclerosis (Tourtelotte, 1970; Norrby, 1978; Salmi et al., 1982).

ACKNOWLEDGMENTS. This work was performed in the Department of Immunology at Scripps Clinic and Research Foundation and was supported by U.S. Public Health Service Grants NS-12428 and AI-16102 from the National Institutes of Health. We are grateful to Hanna A. Lewicki for expert technical assistance, to Michael B. A. Oldstone and Aimo A. Salmi for helpful discussion, and to Dominique D'Ascola Paquet and Lucie Summerside for typing the manuscript. P.J.T. was recipient of a Medical Research Council of Canada Fellowship during the study and currently is recipient of a National Sciences and Engineering Research Council of Canada Scholarship. R.L.K. was the Ralph I. Strauss Fellow of the National Multiple Sclerosis Society during the study and currently is recipient of Teacher Investigation Award NS00803 from the National Institute of Neurological, Communicative Disorders and Stroke. M.J.B. is an established investigator of the American Heart Association.

\section{REFERENCES}

Armstrong, J., Niemann, H., Smeekens, S., Rottier, P., and Warren, G., 1984, Sequence and topology of a model intracellular membrane protein, E1 glycoprotein, from a coronavirus, Nature 308:751-752.

Bailey, O. T., Pappenheimer, A. M., Cheever, F., and Daniels, J. B., 1949, A murine virus (JHM) causing disseminated encephalomyelitis with extensive destruction of myelin. II. Pathology, J. Exp. Med. 90:195-212. 
Buchmeier, M. J., and Knobler, R. L., 1984, Experimental models for immune-mediated and immune-modulated diseases, in: Neuroimmunology (P. Behan and F. Spreafico, eds.), Raven Press, New York, pp. 219-228.

Buchmeier, M. J., Lewicki, H. A., Talbot, P. J., and Knobler, R. L., 1984, Murine hepatitis virus-4 (strain $\mathrm{JHM}$ ) induced neurologic disease is modulated in vivo by monoclonal antibody, Virology 132:261-270.

Cheever, F. S., Daniels, J. B., Pappenheimer, A. M., and Bailey, O. T., 1949, A murine virus (JHM) causing disseminated encephalomyelitis with extensive destruction of myelin. I. Isolation and biological properties of the virus, J. Exp. Med. 90:181-194.

Collins, A. R., Knobler, R. L., Powell, H., and Buchmeier, M. J., 1982, Monoclonal antibodies to murine hepatitis virus-4 (strain JHM) define the viral glycoprotein responsible for attachment and cell-cell fusion, Virology 119:358-371.

Fleming, J. O., Ting, J. Y. P., Stohlman, S. A., and Weiner, L. P., 1983, Improvements in obtaining and characterizing mouse cerebrospinal fluid. Application to mouse hepatitis virus-induced encephalomyelitis, J. Neuroimmunol. 4:129-140.

Fujinami, R. S., and Oldstone, M. B. A., 1985, Amino acid homology between the encephalitogenic site of myelin basic protein and virus: Mechanism for autoimmunity, Science 230:1043-1045.

Gonzalez-Scarano, F., and Nathanson, N., 1985, Viral etiology of multiple sclerosis-a critique of the evidence, in: Subviral Pathogens of Plants and Animals: Viroids and Prions (K. Maramorosch and J. J. McKelvey, eds.), Academic Press, New York, pp. 465-482.

Haspel, M. V., Lampert, P. W., and Oldstone, M. B. A., 1978, Temperature-sensitive mutants of mouse hepatitis virus produce a high incidence of demyelination, Proc. Natl. Acad. Sci. U.S.A. 75:4033-4036.

Holmes, K. V., Doller, E. W., and Sturman, L. S., 1981, Tunicamycin resistant glycosylation of a coronavirus glycoprotein: Demonstration of a novel type of viral glycoprotein, Virology 115:334-344.

Knobler, R. L., Haspel, M. V., and Oldstone, M. B. A., 1981a, Mouse hepatitis virus type 4 (JHM strain)induced fatal central nervous system disease. I. Genetic control and the murine neuron as the susceptible site of disease, J. Exp. Med. 153:832-843.

Knobler, R. L., Dubois-Dalcq, M., Haspel, M. V., Claysmith, A., Lampert, P. W., and Oldstone, M. B. A., 1981b, Selective localization of wild-type and mutant mouse hepatitis virus (JHM strain) antigens in CNS tissue by fluorescence, light and electron microscopy, J. Neuroimmunol. 1:81-92.

Knobler, R. L., Lampert, P. W., and Oldstone, M. B. A., 1982, Virus persistence and recurring demyelination produced by a temperature-sensitive mutant of MHV-4, Nature 298:279-280.

Lampert, P. W., Sims, J. K., and Kniazeff, A. J., 1973, Mechanism of demyelination in JHM virus encephalomyelitis, Acta Neuropathol. 24:76-85.

Luria, S. E., Darnell, J. E., Jr., Baltimore, D., and Campbell, A., 1978, General Virology, 3rd ed., John Wiley \& Sons, New York, p. 417.

MacNaughton, M. R., 1982, Occurrence and frequency of coronavirus infections in humans as determined by enzyme-linked immunosorbent assay, Infect. Immun. 38:419-423.

Niemann, H., and Klenk, H.-D., 1981, Coronavirus glycoprotein E1, a new type of viral glycoprotein, J. Mol. Biol. 153:993-1010.

Norrby, E., 1978, Viral antibodies in multiple sclerosis, Prog. Med. Virol. 24:1-39.

Rygaard, J., 1975, Thymus and Self. Immunobiology of the Mouse Mutant Nude, John Wiley \& Sons, New York.

Salmi, A., Ziola, B., Hovi, T., and Reunanen, M., 1982, Antibodies to coronaviruses OC43 and 229E in multiple sclerosis patients, Neurology 32:292-295.

Siddell, S., Wege, H., and ter Meulen, V., 1982, The structure and replication of coronaviruses, Curr. Top. Microbiol. Immunol. 99:131-163.

Siddell, S. G., Anderson, R., Cavanagh, D., Fujiwara, K., Klenk, H. D., Macnaughton, M. R., Pensaert, M., Stohlman, S. A., Sturman, L., and Van Der Zeijst, B. A. M., 1983, Coronovaridae, Intervirology 20:181-189.

Sorensen, O., Coulter-Mackie, M. B., Puchalski, S., and Dales, S., 1984, In vivo and in vitro models of demyelinating disease. IX. Progression of JHM virus infection in the central nervous system of the rat during overt and asymptomatic phases, Virology 137:347-357.

Sturman, L. S., and Holmes, K. V., 1983, The molecular biology of coronaviruses, Adv. Virus Res. 28:35-112.

Sturman, L. S., Holmes, K. V., and Behnke, J., 1980, Isolation of coronavirus envelope glycoproteins and interaction with the viral nucleocapsid, J. Virol. 33:449-462. 
Sturman, L. S., Ricard, C. S., and Holmes, K. V., 1985, Proteolytic cleavage of the E2 glycoprotein of murine coronavirus: Activation of cell-fusing activity of virions by trypsin and separation of two different 90K cleavage fragments, J. Virol. 56:904-911.

Talbot, P. J., Salmi, A. A., Knobler, R. L., and Buchmeier, M. J., 1984, Topographical mapping of epitopes on the glycoproteins of murine hepatitis virus-4 (strain JHM): Correlation with biological activities, Virology 132:250-260.

Talbot, P. J., Salmi, A. A., Knobler, R. L., and Buchmeier, M. J., 1985, Epitope-specific antibody response to murine hepatitis virus-4 (strain JHM), J. Immunol. 134:1217-1224.

Tourtelotte, W., 1970, On cerebrospinal fluid immunoglobulin-G (IgG) quotients in multiple sclerosis and other diseases, J. Neurol. Sci. 10:279-304.

Vandvik, B., 1973, Immunopathological aspects in the pathogenesis of subacute sclerosing panencephalitis, with special references to the significance of the immune response in the central nervous system, Ann. Clin. Res. 5:308-315.

Weiner, L. P., 1973, Pathogenesis of demyelination induced by mouse hepatitis virus (JHM virus), Arch. Neurol. 28:298-303.

Wolinsky, J. S., Berg, B. O., and Maitland, C. J., 1976, Progressive rubella panencephalitis, Arch. Neurol. 33:722-723.

Woodward, J. G., Matsushima, G., Frelinger, J. A., and Stohlman, S. A., 1984, Production and characterization of $\mathrm{T}$ cell clones specific for mouse hepatitis, strain JHM: In vivo and in vitro analysis, J. Immunol. 133:1016-1021. 